\title{
ПРОБЛЕМЫ В ОТНОШЕНИЯХ МЕЖДУ ДЕТЬМИ И РОДИТЕЛЯМИ ПО ДАННЫМ РУССКИХ ПАРЕМИЙ
}

\section{PROBLEMS IN RELATIONS BETWEEN CHILDREN AND PARENTS ACCORDING TO RUSSIAN PAREMIAS \\ S. Skhalyakhova \\ O. Mullinova \\ T. Mullinova}

Summary: Adhering to a broad view of the composition of the paremiological fund, the authors of the article turn to sayings and aphorisms reflecting intra-family relations, namely, the attitude of children towards their parents, which until now has remained outside the scope of linguistic research. The main problem of these relations, according to Russian paremias, was the loneliness of children in families. The paremias represent the reasons for this.

Keywords: paremia, linguistic picture of the world, children, parents, family relationships, loneliness.

\author{
Схаляхова Саида Шамсудиновна \\ К.филол.н., дочент, Майкопский государственный \\ технологический университет \\ saida.shal@mail.ru \\ Муллинова Ольга Александровна \\ К.филол.н., дочент, Краснодарское высшее военное \\ авиачионное училище летчиков \\ o.mullinova@mail.ru \\ Муллинова Татьяна Александровна \\ К.филол.н., дочент, Краснодарское высшее военное \\ авиачионное училище летчиков \\ t.a.mullinova@mail.ru
}

Аннотация: Придерживаясь широкого взгляда на состав паремиологического фонда, авторы статьи обращаются к поговоркам и афоризмам, отражающим внутрисемейные отношения, а именно - отношение детей к родителям, что до настоящего времени оставалось за пределами лингвистических исследований. Основной проблемой этих отношений по данным русских паремий оказалось одиночество детей в семьях. Паремии репрезентируют причины этого.

Ключевые слова: паремия, языковая картина мира, дети, родители, внутрисемейные отношения, одиночество.

паремий является их несомненный вклад в развитие и совершенствование цивилизации в целом, нации в частности, а также каждой языковой личности как члена определенного социума. Паремии являются аккумулятором опыта поколений и действенным средством воспитания: «Как узуально-поведенческие тексты, пословицы и афоризмы иллюстрируют различные аксиомы поведения (аксиомы жизнеобеспечения, взаимодействия, ответственности, общения, реализма, безопасности, благоразумия, управления)» [4, с. 2].

К сожалению, в настоящее время престижность знания паремий значительно упала, особенно в молодежной среде, перестало быть актуальным чтение сборников пословиц и поговорок, афоризмов. Это приводит к тому, что утрачивается связь поколений, в результате чего молодые люди оказываются перед печальной необходимостью многое уже понятое и осознанное ранее предыдущими поколениями открывать для себя заново, а смысл ряда паремий просто не понимают. Они не осознают того факта, что знание пословиц, поговорок, афоризмов способно расширить их словарный запас, быть надежным ориентиром в ряде жизненных ситуаций, поможет развить интеллект и чувство языка, расширить и улучшить способность процесса понимания, приблизить к уровню высокоразвитой сильной языковой личности, вооружить действенными аргументами в речевой 
коммуникации, в дискуссиях и спорах.

Знание паремий и умелое владение ими необходимо каждому человеку для постижения языковой картины мира и достойного уровня обладания ею. «Языковая картина мира создает знаковый облраз действительности, ее интерпретацию. Словесные образы вещей и лингвистические модели, отражающие специфические особеннолсти национального языка, дополняют видение мира. Они становятся одним из источников познания, осмысления действительности, сполсобствуют воспроизведению более полной и всесторонней картины окружающей действительности в сознании людей. Национально-культурное своеобразие определяют история, традиции, символы, мифы. Картина мира лингвокультурного сообщества в целом формируется языком как средством воплощения тех или иных культурных установок, стереоᄀтипов, символов, эталонов и т.п., которые организуют данный солциум в сообщество» [7, с. 211]. Одним из средств вербализации картины мира являются паремии.

Паремии в отечественном языковедении изучаются активно и достаточно разнопланово. Существует немало научных исследований, посвященных паремиологии семейных отношений. Широко исследованными можно считать паремии, отражающие отношения супругов, отношение родителей к детям, вопросы воспитания, поучения и назидания в адрес подрастающего поколения. Однако наши наблюдения показывают, что практически неизученным остается тот аспект семейных отношений, который отражает отношение детей к родителям. Самих паремий такого рода существует очень немного, особенно по сравнению с количеством паремий назидательного характера. Это объяснимо: пословицы, поговорки, афоризмы создаются не детьми, а взрослыми, и, разумеется, отражают картину мира взрослого человека, а не ребенка: по мере взросления детские впечатления и мечты забываются, перестают казаться актуальными, перекрываются иными впечатлениями, знаниями и заботами. Вполне очевидно, что редкие паремии, в которых говорится об отношении детей к родителям, созданы по личным воспоминаниями взрослых о своем детстве и как результат наблюдений над собственными детьми. Таким образом, картина мира детей в указанных паремиях представлена не прямо, а опосредованно - от лица людей другого возраста.

Разумеется, в рамках одной статьи невозможно полностью и разносторонне исследовать паремии, в которых отражены представления детей о родителях, но мы считаем необходимым обозначить проблему и наметить некоторые аспекты ее рассмотрения.

Предварительно отметим, что непростое отношение к детям ряда людей выражено в таком противоречивом высказывании: «Имеешь детей - радуйся, не имеешь, тоже радуйся» или его вариант: «Я радуюсь, когда ко мне приезжают дети и радуюсь, когда они уезжают» [3].

В части паремий, посвященных отношению детей к родителям, показано положительное влияние старших, например:

«Не надобно другого образца, когда в глазах - пример отиа» (А.С. Грибоедов) [5].

«Все смертно. Вечная жизнь суждена только матери. И когда матери нет в живых, она оставляет по себе воспоминание, которое никто еще не решился осквернить. Память о матери numaem в нас сострадание, как океан, безмерный океан питает реки, рассекающие вселенную...» (И.Э. Бабель) [5].

Однако имеют место также и негативные ситуации. Одной из проблем, представленных в паремиях, посвященных отношению детей к родителям, является одиночество малышей при живых родителях. Одиночеством в чистом виде его назвать нельзя - это не одиночество человека, находящегося где-либо отдельно от других, а ощущение одинокости, покинутости в кругу самых близких родственников. В афоризмах названы основные причины такого одиночества детей - это излишняя строгость, жестокость, черствость и высокомерие родителей, их частые отлучки из дома:

«Когда ребенка пугают, порют и всячески огорчают, тогда он с самых малых лет начинает чувствовать себя одиноким» (Д.И. Писарев) [5].

«Трагедия неразделенной любви взрослого меркнет в сравнении с трагедией неразделенной любви ребенка к матери» (И.Н. Шевелев) [5].

«Чем длительнее разлука между родителями и детьми, тем больше родители любят детей, тем меньше дети любят родителей» (И.Н. Шевелев) [5].

«Никогда не показывайте, что вы умнее ребенка: почувствовав ваше превосходство, он, конечно, будет уважать вас за глубину мысли, но сам сейчас же молниеносно уйдет в себя, спрячется, как улитка в раковину» (А.Т. Аверченко) [5].

Самая главная причина одиночества ребенка в семье - отсутствие выражения искренней любви со стороны взрослых или прямая демонстрация нелюбви:

«Ребенок знает свою душу, он любит ее и бережет ее, как веко бережет глаз. И без ключа любви никого в нее не пускает...» (Т.А. Ергольская) [5].

«Плохо, когда ребенок не видит любви. Хорошо, когда не видит нелюбви» (А.А. Лиханов) [5].

Завоевать любовь и уважение ребенка подарками невозможно:

«Счастливое детство создается из любви родителей, а не количества денег» [8].

«Любовь мамы и ум папы - вот что нужно ребёнку для счастья, а не какая-то там игрушка» [8]. 
Нелюбимый или «недолюбленный» ребенок закрывается от мира взрослых, уходит в себя и ждет только того, чтобы его не трогали, даже чтобы не спрашивали ни о чем, что обыгрывается в печально-ироничном высказывании Е. Шварца: «Воспитанные дети не задают вопросов старшим. Они ждут, пока старшие сами не зададут им вопрос» [5].

Видимо, постоянная занятость взрослых, их невнимание к собственным детям могут быть компенсированы в основном общением с братьями и сестрами. Вот почему «Единственный ребенок в семье всегда несчастен и одинок» (Э. Лимонов) [5].

Варианты ответного поведения родителей на одиночество и закрытость их детей в основном лежат в двух плоскостях: либо, заметив проблему, сразу же начинают исправлять ее (афоризм А. Алексина), либо имитировать настоящие отношения, что, однако, ни к чему хорошему не приведёт (высказывание Л. Гурченко):

«Дети, как уверяют, рождаются для того, чтобы лишить своих родителей эгоизма...» (А. Алексин) [5].

«Когда до отчаяния сознаю, что я плохая мать, - начинаю впопыхах наверстывать упущенное, подлизываться и угождать. Но в этой профессии потери не наверстаешь» (Л.М. Гурченко) [5].

Отчуждение детей от родителей может быть вызвано разностью мировоззрений между поколениями, влиянием внешних воздействий и полученных жизненных навыков:

«Наши дети старше нас, потому что им дольще, дальше жить. Старше нас из будущего. Поэтому иногда нам и чужды» (М.И. Цветаева) [5].

«Сначала родители учат детей жизни, а потом дети учат родителей выживать в жестком и изменившемся мupe...» [8].

Но, конечно, основная проблема - сами родители, их плохое воспитание, жесткость, бескомпромиссность, неуступчивость, неспособность понимать внутренний мир другого человека:

"Дети не рождаются плохими. Плохими бывают родители, которые этих детей воспитывают...» [8].

«Родители - это такие люди, которые не способны тебе простить то, чем сами гордились в твоём возрасте» [8].

Однако и дети часто бывают лукавыми, нетерпимыми, жесткими, не способными прощать:

«Родители снисходительны к детям; дети бескомпромиссны к родителям» (И.Н. Шевелев) [5].

«Мама - это человек, которого мы любим дольше всех, но лжем ей чаще других...» [8].

Среди распространенных пороков детей, разрушающих семейные отношения, - избалованность и приспособленчество, нежелание взрослеть и становиться ответственными, прилагать усилия для своего развития:

«Природа отдыхает на детях гениев, а дети гениев на родителях» (Г. Малкин) [5].

«Отпрыски "звёзд" чаще всего становятся астероидами» (Г. Стернин) [1].

В ряде афоризмов говорится о том, что неумение и нежелание детей любить своих родителей заложено от природы, что сильна лишь родительская, а не сыновняя и дочерняя любовь:

«Свой долг родителям дети отдают своим детям» (И.Н. Шевелев) [5].

«Своих детей мы, как правило, любим гораздо сильнее, чем собственных родителей» [8].

«Дети - отличное прикрытие, чтоб предаваться незатейливым радостям жизни: скакать с мячом, в реке плескаться, в снежки играть, на саночках кататься... А вырос - тут... вся надежда на внуков!» [9].

Итак, в паремиологическом фонде русского языка нашла отражение такая проблема, как ощущение ребенком одиночества в кругу своей семьи. Неумение воспитывать и любить детей по-настоящему, сухость, излишняя придирчивость и авторитарность со стороны родителей могут не только разрушить взаимопонимание между поколениями, но и сломать детям жизнь. Однако есть надежда на то, что ребенок, выросший в доброй, любящей семье у разумных отца и матери не только не почувствует горечи отчуждения, но и станет достойной опорой для родителей: «Не ограничивайте ребенка. Не обрезайте его крылья. Давайте ему выбрать свою дорогу. Знайте, расправив свои крылья однажды, он не даст опуститься вашим» [9].

\section{ЛИТЕРАТУРА}

1. Афористика и карикатура. Антология Сатиры и Юмора России XX века. Т. 24. М.: Изд-во Эксмо, 2004.

2. Дмитриева 0.А. Культурно-языковые характеристики пословиц и афоризмов (на материале французского и русского языков): автореф. дис. ... канд. филол. наук: 10.02.20. Волгоград, 1997. 18 с.

3. Женщина золотого возраста. http://www.np-press.ru/materialy-vypuska/intervyu/4519-zhenshchina-zolotogo-vozrasta (дата 0бращения: 19.07.2021).

4. Карасик В.И. Оценочная мотивировка, статус лица и словарная личность // Филология-Philologica. 1994. № 3. С. 2-7.

5. Мудрость России. Афоризмы / авторы-составители Кожевников А.Ю., Линдберг Т.В. СПб.: Нева, 2005. 536 с. 
6. Натхо 0.И. Английские паремии в языковой картине мира // Язык. Текст. Дискурс: Научный альманах. Вып. 7. Ставрополь: СГПИ, 2009. С. $433-439$.

7. Рядчикова Е.Н., Бутто 0.Л., Схаляхова С.Ш. Концепты «венчание», «брак», «семья», «жена» и национальный менталитет. Germany, Saarbrücken: Palmarium Academic Publishing, 2012. $240 \mathrm{c}$.

8. https://novye-statusy.ru/tsitaty-pro-roditelej.html (дата обращения: 19.07.2021).

9. https://www.romanticcollection.ru/lovestory/citaty-i-aforizmy-pro-detey (дата обращения: 19.07.2021).

(с Схаляхова Саида Шамсудиновна (saida.shal@mail.ru), Муллинова Ольга Александровна (o.mullinova@mail.ru), Муллинова Татьяна Александровна (t.a.mullinova@mail.ru).

Журнал «Современная наука: актуальные проблемы теории и практики»

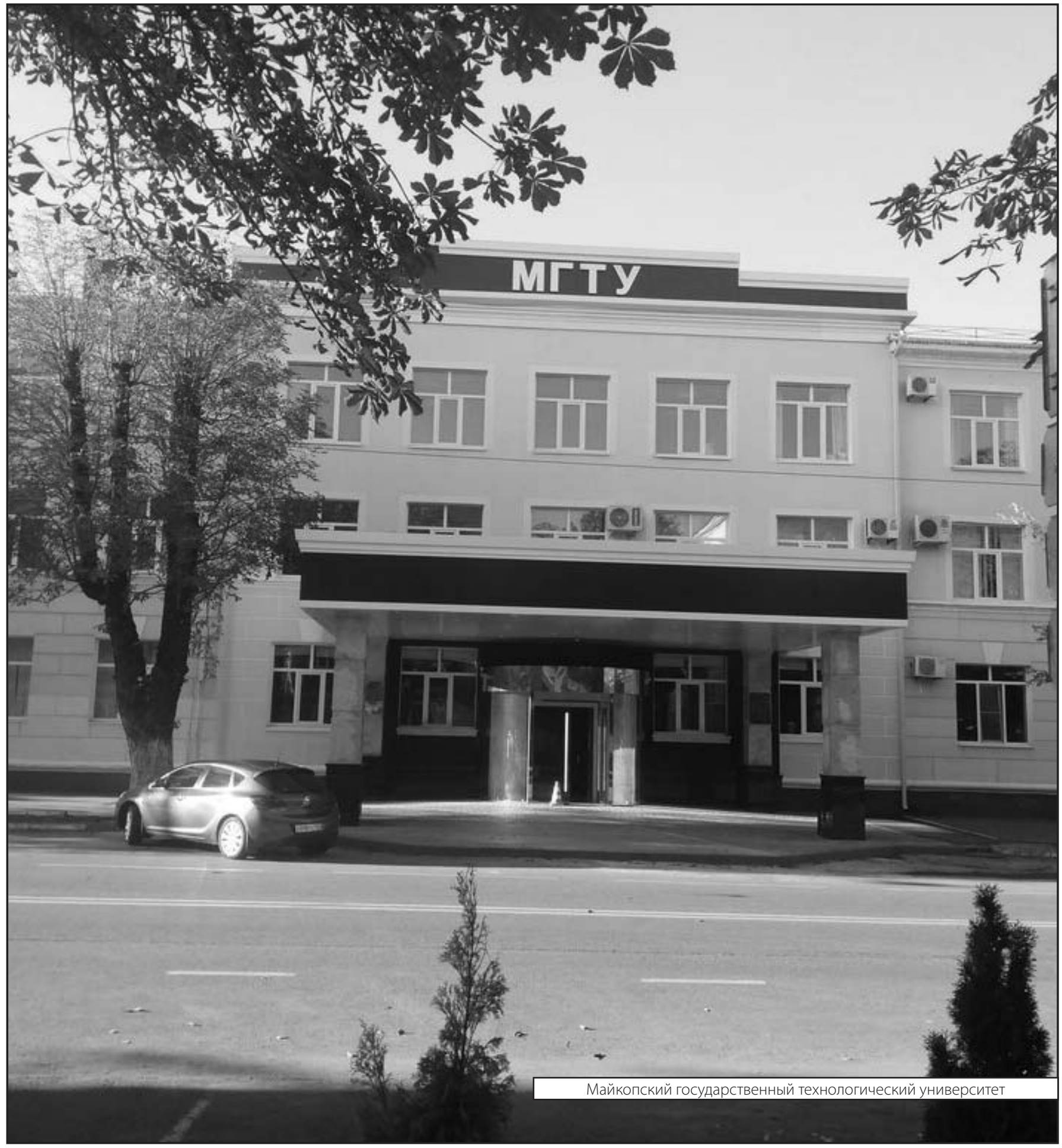

